\title{
DOCTORAL DISSERTATIONS SUPERVISED BY OLLI LEHTO
}

1. JUSSI VäISÄLÄ: On normal quasiconformal functions. Ann. Acad. Sci, Fenn. Ser. A. I. 266, 1959, 33 pp.

2. MARTTI TIENARI: Fortsetzung einer quasikonformen Abbildung über einen Jordanbogen. Ibidem 321, 1962, $32 \mathrm{pp}$.

3. Reino KuRKI-SUONIO: On some sets of formal grammars. Ibidem 349, 1964, $31 \mathrm{pp}$.

4. OSSI TAARI: Charakterisierung der Quasikonformität mit Hilfe der Winkelverzerrung. Ibidem 390, 1966, 43 pp.

5. Kalevi Suominen: Quasiconformal maps in manifolds. Ibidem 393, 1966, 39 pp.

6. SePPo Rickman: Characterization of quasiconformal arcs. Ibidem 395, 1966, $30 \mathrm{pp}$.

7. Olli Martio: Boundary values and injectiveness of the solutions of Beltrami equations. Ibidem 402, 1967, $27 \mathrm{pp}$.

8. TAPANI KUUSALO: Verallgemeinerter Riemannscher Abbildungssatz und quasikonforme Mannigfaltigkeiten. Ibidem 409, 1967, 24 pp.

9. MARJATTA NäÄTÄNEN: Maps with continuous characteristics as a subclass of quasiconformal maps. Ibidem 410, 1967, 28 pp.

10. SaKari Toppila: Picard sets for meromorphic functions. Ibidem 417, 1967, 24 pp.

11. TUOMAS SORVALI: The boundary mapping induced by an isomorphism of covering groups. Ibidem 526, 1972, $31 \mathrm{pp}$.

12. Timo ERKAMA: Group actions and extension problems for maps of balls. Ibidem 556, 1973, $31 \mathrm{pp}$.

13. ZERRIN GÖKTÜRK: Estimates for univalent functions with quasiconformal extensions. Ibidem 589, 1974, $21 \mathrm{pp}$.

14. Matti Lehtinen: On locally affine mappings of Riemann surfaces. Ann. Acad. Sci. Fenn. Ser. A. I. Math. Dissertationes 2, 1975, 36 pp.

15. Mika SEPpÄLÄ: Teichmüller spaces of Klein surfaces. Ibidem 15, 1978, 37 pp. 16. Aimo HinkKanen: On the averages of the counting function of a meromorphic function. Ibidem 26, 1980, $31 \mathrm{pp}$.

17. Juhani V. VAinio: Conditions for the possibility of conformal sewing. Ibidem 53, 1985, 43 pp.

doi:10.5186/aasfm.1985.1003 